

\section{DISCLAIMER}

This report was prepared as an account of work sponsored by an agency of the United States Government. Neither the United States Government nor any agency Thereof, nor any of their employees, makes any warranty, express or implied, or assumes any legal liability or responsibility for the accuracy, completeness, or usefulness of any information, apparatus, product, or process disclosed, or represents that its use would not infringe privately owned rights. Reference herein to any specific commercial product, process, or service by trade name, trademark, manufacturer, or otherwise does not necessarily constitute or imply its endorsement, recommendation, or favoring by the United States Government or any agency thereof. The views and opinions of authors expressed herein do not necessarily state or reflect those of the United States Government or any agency thereof. 


\section{DISCLAIMER}

Portions of this document may be illegible in electronic image products. Images are produced from the best available original document. 


\title{
Assessment of Speciation Techniques Including the Application of Photoacoustic Spectroscopy
}

\author{
J. Bucher, H. Gehmecker, and N. Edelstein
}

Lawrence Berkeley Laboratory

University of California

Berkeley, Callfornia 94720

August 1985

\section{DISCLAIMER}

This report was prepared as an account of work sponsored by an agency of the United States Government. Neither the United States Government nor any agency thereof, nor any of their employees, makes any warranty, express or implied, or assumes any legal liability or responsibility for the accuracy, completeness, or usefulness of any information, apparatus, product, or process disclosed, or represents that its use would not infringe privately owned rights. Reference herein to any specific commercial product, process, or service by trade name, trademark, manufacturer, or otherwise does not necessarily constitute or imply its endorsement, recommendation, or favoring by the United States Government or any agency thereof. The views and opinions of authors expressed herein do not necessarily state or reflect those of the United States Government or any agency thereof.

(SRPO) under Contract No. E51184025 U.S. Salt Repository Project office of Energy under Contract No. DE-ACO3 and in part by the U.S. Department 


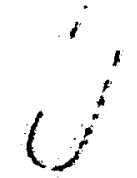

secondary-phase formation or mixed compound insolubility alone.

Although the redox information will not place any additional demands upon the barrier enginering requirements, it will clearly confirm that the unmodified near-fleld components (e.8.. Iron cannister material, the overpack, etc.) are controlling the Eh and/or $\mathrm{pH}$ conditions appropriately. It 18 expected that speciation study results will Indlcate the solution-phase existence of tervalent or trivalent lons. Representative examples are uranium, $U^{4+}$ and 1 ts hydrolysis products $U(\mathrm{OH})_{x}^{4-x^{+}}$, neptunium, Np(OH)$)_{x}^{4-x^{+}}$techneclum, $\mathrm{IC}^{4+}$ (or $? \mathrm{TCO}^{2+}$ ); plutonium, $\mathrm{Pu}^{3+}$ ( $\mathrm{Pu}(\mathrm{OH})_{\mathrm{x}}^{3-\mathrm{x}^{+}}$, with a possible intermediate trivalent solid phase, $\left.\mathrm{Pu}(\mathrm{OH})_{3}\right)$, and $\mathrm{Am}_{\mathrm{m}}(\mathrm{OH})_{\mathrm{x}}^{3-\mathrm{x}^{+}}$, all under reducing Eh conditions. These studies will also provide experimental verification of modeling codes and the data base.

In contrast to the above ultra-trace conditions, when the solutionphase solubilities exceed $10^{-7}-10^{-8} \mathrm{M}$ (solublilty situdies), identification of the solution-phase redox species is no longer simply a matter of providing supplementary confirming information. Solution speciation results are now a necessity and w11l indicate what types of remedial conditions need to be included in the engineered near-rield barrier in order to prevent radionuclide migration beyond the barrier boundary at an unacceptable concentration level. Speciation results w111 indicate whether an Eh or a pH adjustment, or both, are needed to establish satisfactory solubility-1imiting behavior. These studies will help declde whether the general redox conditions are being controlled by radiation induced or naturally occurring redox agents $\left(e . \mathrm{g}_{0}, \mathrm{O}_{2}, \mathrm{Fe}^{2+}\right)$. 
Techniques need to be developed so that the solld-phase is characterizable even if it is amorphous or is in a mixed phase of radionuclides-cannister-corrosion products.

The two most ut1lized approaches to the determination of solutionphase species involve separation or spectroscoplic techniques. Separation procedures are based mainly upon ion selective interactions and are thus sensitive to oxidation states. These procedures include. such familiar methods as organic lon-exchange resin chromatography, solvent extraction, and the less often encountered varlations on these methods: Inorganic lon-exchange chromatography and flxed-phase solvent extraction systems.

These methods are usually applied using low pressure techniques. The use of high-pressue 11 quid chromatographic (HPLC) techniques, a standard technique used in separating blological materials, has not been frequently employed in separating inorganic materials. HPLC can give rapid separations and thus preserve the desired redox speciation information even under difficult experimental redox conditions. This occurs by taking advantage of the fairly slow kinetic reactions of the Important radionucildes (1.e., TC, U, Np, Pu).

Chromatography Application

To illustrate the application of separation methodology to the problem of radionuclide oxidation state speciation, results from the doctoral thesis ${ }^{1}$ of a co-worker, Dr. Horst Gehmecker are presented. His objective was to explore the separation and identification of plutonium oxidation state distributions at low concentrations as might be found in 
groundwater. He used commonly avallable separation materiais and established the experimental conditions under which useful workable schemes for oxidation state distributions could be clearly demonstrated. Experiments were primarily done at total plutonium concentrations of $10^{-7} \mathrm{M}$ or less.

F1g. 1 shows the plutonium distribution coefficients $\left(K_{D}\right)$ as a function of oxidation state $\left(\mathrm{Pu}^{3+}, \mathrm{Pu}^{4+}, \mathrm{PuO}_{2}^{2+}\right)$ and as a runction of HCl concentration for the strong acid organic ion-exchange resin, Dowex 50W-X8. Th1s data suggests that lon-exchange columns can be used for a satisfactory plutonium oxidation state separation by using a single HCl concentration between $1--7 \mathrm{M}$. The important featureein Figure 1 is the noncrossing of the individual oxidation state distribution coefficients curves unt11 high HCl concentrations (> $8.5 \mathrm{M}$ ) are used. This means the elution order would be $\mathrm{PuO}_{2}^{+}, \mathrm{PuO}_{2}^{2+}, \mathrm{Pu}^{3+}, \mathrm{Pu}^{4+}$, operation at a rixed acid concentration means that a) if a low HCl concentration is used. large volumes are necessary to elute the plutonium species, or b) if a higher HCl concentration is used, a long column is necessary, as the differences in distribution coefficients are small. A third mode of operating an Ion-exchange column is shown in Fig. 2

Instead of using a fixed acid concentration, a step-wise change of acidity is made, so that each oxidation state is selectively eluted from the lon-exchange column in a relatively small solution volume. The total volume needed for separating all the plutonlum species is also small. Finer adjustment of the final acidity change could be made to obtain a $\mathrm{Pu}^{3+}, \mathrm{Pu}^{4+}$ separation. But, as seen later, this may not be a necessary step when a combination of other techniques are included. 
Figures 3 and 4 detall the distribution coefficients for Pu in the sytem tributylphosphate (TBP)-nitric acid. TBP is representative of neutral solvent-extraction systems and diluted TBP is the main reagent used in nuclear fuel reprocessing. Flgure 3 shows the extraction behavior of $\mathrm{Pu}$ Into a pure TBP phase from various nitric acid concentrations. Figure 4 is simliar except the TBP has been sorbed upon an inert stationary material (polytrifluorochloroethylene polymer. usually known as Kel-F). This $\mathrm{flxed-phase} \mathrm{materlal} \mathrm{can} \mathrm{be} \mathrm{used} \mathrm{in} \mathrm{a}$ column form. It is evident from both Figures 3 and 4 that the selectivity for $\mathrm{Pu}^{4+}$ and $\mathrm{PuO}_{2}^{2+}$ is nonexistent. However, the difference In distribution coefficients for $\mathrm{Pu}^{4+}$ and $\mathrm{Pu}^{3+}$ is good and could be particularly useful in oxidation state speciation studies of Pu under reducing conditions. Figure 5 shows the effect of using acids other than nitric with TBP. Only the TBP-perchloric acid system shows any potential for useful species separations.

A more useful solvent extraction system is shown in Figures 6 and 7. The material, di-(2-ethylhexyl) phosphoric acid (HDEHP) is a moderately strong acid. When sorbed upon an inert fixed-phase it is similar to the previously discussed Dowex 50 cation Ion-exchange resin. Also included in Figure 7 is information on $\mathrm{PuO}_{2}^{+}$distribution. As before in the TBP system, no clear discrimination between $\mathrm{Pu}^{4+}$ and $\mathrm{PuO}_{2}^{2+}$ is possible in these HDEHP/acid system. This may not, however, be any more than an experimental inconvenience. Unless the $\mathrm{Pu}$ concentration is sufficiently high so that disproportionation reactions are occurring, it is unlikely $\mathrm{Pu}^{4+}$ and $\mathrm{PuO}_{2}^{2+}$ would coexist. The very large distribution coefficients for $\mathrm{Pu}^{3+}, \mathrm{Pu}^{4+}$, and $\mathrm{PuO}_{2}^{2+}$ in this HDEHP system at low 
acidities, would allow its use for concentrating plutonium (and the other analogous actinide systems $\mathrm{Np}$ and $U$ ) species from large volumes of test solutions. This ability to concentrate specles without losing redox information would be especially userul in increasing the detection IImit sensitivity for other actinide systems such as neptunium under reducing conditions. In order to remove el ther $\mathrm{Pu}^{4+}$ or $\mathrm{PuO}_{2}^{2+}$ from this type of column it is necessary to use a reducing agent (ascorbic acid) so that $\mathrm{Pu}^{3+}$ is formed.

F1gures $8,9,10$, and 11 show the results for plutonium separations from both specially prepared s1lica gel and for s111ca gel that has been sulfonated. The silica gel used (Merck, L1Chrospher S1 100, $10 \mathrm{rm}$ particle size) has a large surface area, - $250 \mathrm{~m}^{2} / \mathrm{gm}$, and results in an Ion absorptive capacity of -2 meq/gm. This capacity $1 \mathrm{~s}$ simllar in magni tude to a typical organic based cation or anion 1on-exchange resin. The other material used is formed by attaching a sulfonic acid group, $\mathrm{SO}_{3}^{-}$, to the s1lica backbone to give: $-\$ 1-0-\mathrm{SO}_{2}^{-}$groups. Th1s materlal acts as a strong acid cation exchanger. Unlike its organic based resin counterpart, the sulfonated sllica gel has no tendency to perturb the speciation by redox reactions as the gel has no reducing properties. Figure 8 shows the distribution coefficients for absorption of $\mathrm{Pu}^{3+}, \mathrm{Pu}^{4+}$, and $\mathrm{PuO}_{2}^{2+}$ on L1Chroprep SI 60 (a 20 um sized equilvalent to LIChrospher SI 100), as a function of HCl concentration. At low acidities a strong selectivity for $\mathrm{Pu}^{4+}$ (and presumably any tervalent actinide or higher charged (1sston product lon) over $\mathrm{Pu}^{3+}$ and $\mathrm{PuO}_{2}^{2+} 1 \mathrm{~s}$ clearly evident. Yet, at high acid concentrations, even Pu ${ }^{4+}$ can be 
easily eluted. For effective absorption of tervalent plutonium, a 2.5-3 $h r$. contact time is needed during the loading phase of the solution.

Figure 9 shows the selectivity of LiChrospher SI 100 when used in an absorption column. Loading is done at $0.01 \mathrm{M} \mathrm{HClO}_{4}$; desorption of $\mathrm{Pu}^{4+}$ is done with $5 \mathrm{M} \mathrm{HCl}$. Experiments were run at a $10^{-8} \mathrm{M}$ plutonium level.

Figures 10 and 11 detall the behavior of plutonium on sulfonated sillca material. Figure 10 shows that a complete $\mathrm{Pu}^{3+}, \mathrm{Pu}^{4+}, \mathrm{PuO}_{2}^{+}$, and $\mathrm{PuO}_{2}^{2+}$ redox separation can be achleved when moderate stepwise acidity changes are used. The conditions necessary for $\mathrm{Pu}^{3+}$ and $\mathrm{Pu}^{4+}$ elution are considerably milder than needed in the Dowex 50 cation Ion-exchange experiments.

Figure 11 shows similar data for oxidation state mixtures. The data also indicates that when phosphoric acid is used to elute the $\mathrm{Pu}^{4+}$ fraction, a considerably smaller volume of eluant is needed. Experiments were run at total plutonium concentrations of e1ther $-10^{-9} \mathrm{M}$ or $10^{-8} \mathrm{M}$. No separation differences were observed with these ultra-trace concentration levels.

F1gure 12 shows several flow sheets proposed by Gehmecker. They Incorporate the use of two connected columns in each example. The first column contains sillca material (see Fig. 8) which is selective for tervalent lons and retalns this oxidation state, while the other redox species flow stralght through to a second column. As Indicated, the cholce of using el ther Dowex $50-\times 8$ or the sulfonated sillca cation Ionexchanger is equally effective. A slight preference for the system detailed in part a) comes from considering the total eluant volumnes. 
Smaller solution volumes are easier and more efficiently assayed by counting techniques. Also the totally inorganic composition of the sulfonated silica lon-exchange is useful in preventing any species reduction reactions from the column material.

The results in Table 1 lllustrate the effectiveness of these separation techniques for oxidation state speciation determinations. Plutonium concentration levels of the initial mixed redox solutions were $-5 \times 10^{-12}$ M. Initial redox compositions are 11 sted in column 3 and the results determined by counting techniques (errors are at the 20 (s1gma) level) are 11sted in subsequent columns. The agreement between the Initial starting plutonium oxidation state composition and the experimentally determined redox species percentages is extraordinary, especially if one considers the ultra-trace concentration level used. By using a combination of absorption and cation Ion-exchange columns redox speciation determinations are reasible down to the very limits or radionuclide counting detection.

Data are also included in this table which show the efrectiveness of the $\mathrm{LaF}_{3}$ coprecipitation technique for carrying tri- and tervalent actinide species. This technique is presently being used to concentrate large volumes of neptunium species from solubility measurement. Starting with $10^{-9}-10^{-10} \mathrm{M} \mathrm{NpO}_{2}^{+}$solutions in $6 \mathrm{~m} \mathrm{NaCl}$, the $\mathrm{NpO}_{2}^{+} 18$ reduced to $\mathrm{Np}^{4+}$ by $\mathrm{Fe}^{2+}$ and then the $\mathrm{Np}^{4+}$ coprecipitated with $\mathrm{LaF}_{3}$ Thus a $100 \mathrm{ml}$ sample 18 reduced in volume to a few mg of $\mathrm{LaF}_{3}$ precipitate.

Other redox speciation schemes have been given in great detail in the ilterature. 2 They center upon the use of solvent extraction methods 
and the use of TTA (thenoyltrifluoroacetone) is frequently encountered. Most, if not all, of these liquid-11quid phase solvent extraction determinations were performed under oxidizing conditions. It is felt that the use of 1solated absorption and Ion-exchange columns can give better redox speciation results. Th1s is especially useful for the case where redox speciation is examined from solubility studies done under reducing conditions (? repository conditions). Eh conditions in the columns can be maintained in a close approximation to those existing in the reducing test solutions.

Spectroscoplc Applications

Spectroscopic techniques provide more versatile but less sensit1ve methods for speciation studies than separation techniques. All the actinide radionuclides have sharp absorption bands characteristic for each actinide Ion oxidation state. These electronic transitions arise from the $5 f^{n}$ electron configurations and the strength of these transitions 18 seldom large. Dilute solutions of lons or complexes of these elements ( $U, N P, P u$ and $A m$ ) are usually weakly absorbing and more sensitive instrumental technlques are needed for accurate studies.

Table 2 lists the absorption parameters for $U, N p, P U, A m$, and TC (technicium). The entry under wavelength is for the strongest absorption band for each listed radionuclide oxidation state. Molar absorptivity is a parameter that normalizes the absorption process per unit length. The absorption spectroscopy equation is expressed as:

$$
A_{\text {abs }}=A_{0} \cdot \alpha \cdot l \text {, }
$$


where $A_{a b s}$ is the amount of $11 \mathrm{ght}$ absorped, $A_{0}$ is the Initial $11 \mathrm{ght}$ flux, $\alpha$ is the absorbance coefricient and $l$ is the unit length, usually expressed in units of centimeters. The absorbance coefficient, $\alpha$, can be broken Into two components: $c$, the concentration of the absorbing species and $\epsilon$, the extinction coefficient. Thus

$$
A_{a b s}=A_{0} \cdot c \cdot c \cdot L \text {. }
$$

The final column in Table 2 , sensitivity, is an estimate of the lowest concentration detectable for each oxidation state. It is assumed that a) a conventional research UV-VIS-NIR spectrometer is used, b) the minimum detectable absorption on an expanded scale $185 \times 10^{-4}$ absorbance units (signal to nolse ratio $181: 1$ ), and c) the pathlength $181 \mathrm{~cm}$. It is evident that even for the best actinide example, $\mathrm{PuO}_{2}^{2+}$. - $10^{-6}$ M 18 the 11 miting detectable redox species concentration. For the (18sion product radionuclides (e.8., techniclum), an order of magnitude detection sensitivity increase is expected, as the observed transitions are not formally forbidden. Another order of magnitude increase in sensitivity for all the examples $\left(-10^{-7}\right.$ actinide lons, $\left.-10^{-8} \mathrm{Tc}\right)$ can be obtained by using $10 \mathrm{~cm}$ pathlength cells, but the solution volume also lncreases ( $>7 \mathrm{ml}$ needed).

These estinated detection sensitivities are strictly applicable to dilute, low lonic strength solutions, conditions that are found in other than the proposed salt repository sites. In strong salt solutions (e.8., PBB1 or PBB3 prototype brines) the varlous redox species 11sted: In Table 2 will interact with chloride lon, $\mathrm{Cl}^{-}$. This interaction to form chloro complexes reduces markedly the molar absorptivity values ${ }^{3-5}$ and hence the detection sensitivity. Despite this hinderance, useful 
solution redox species determinations can still be done with absorption spectroscopy techniques for several of these actinide systems. The possible systems are principally those that involve a difference in the solution and solld-phase oxidation states. Examples are: $\mathrm{PuO}_{2} \cdot \mathrm{xH}_{2} \mathrm{O}$ (sol1d phase), $\mathrm{PuO}_{2}^{+}$or $\mathrm{PuO}_{2} \mathrm{Cl}_{\mathrm{x}}^{(1-x)}$ (solution phase), and $\mathrm{NpO}_{2} \cdot \mathrm{xH}_{2} \mathrm{O}$. (sol1d phase), $\mathrm{NpO}_{2}^{+}$or $\mathrm{NpO}_{2} \mathrm{Cl}_{\mathrm{x}}^{(1-\mathrm{x})}$, systems $11 \mathrm{kely}$ under oxidizing conditions; and $\mathrm{PuO}_{2} \cdot \mathrm{H}_{2} \mathrm{O}$ (solid phase), $\mathrm{Pu}^{3+}$ or $\mathrm{PuCl}_{\mathrm{x}}^{3-\mathrm{x}}$ (system $11 \mathrm{kely}$ under the strong $\mathrm{Fe}-\mathrm{Fe}^{2+}$ controlled reducing conditions) and $\mathrm{Am}(\mathrm{OH})_{3} \cdot \mathrm{xH}_{2} \mathrm{O}$ or $\mathrm{AmO}_{2} \cdot \mathrm{xH}_{2} \mathrm{O}$ (solld phase). AmCl $e_{x}^{3-x}$ (solution phase) at low pH values and under both oxidizing and reducing conditions. Absorption spectroscopy can be used to identify the solution redox species in each of the above examples because the solution-phase concentration is large () $10^{-5} \mathrm{M}$ ) over some portion of the pH dependent solubility determination study. Obviously, the radionuclide concentration levels needed to apply this technique are at an unacceptable level from a nearfield containment viewpoint. However this type of experimental speciation information is useful to define conditions that are needed to prevent unacceptable radionuclide release conditions. For example, well established Eh and $\mathrm{pH}$ conditions in the near-field boundary could prevent radioactive releases above an acceptable level.

A better use of spectroscopic techniques for speclation studies is shown in Figures 14, 15, 16, and 17. These figures show absorption spectra for $\mathrm{NP}, \mathrm{Pu}$, and Am with various $\mathrm{Cl}^{-}$concentrations and several. other 11gands. As noted before, it is clear that the visible region transitions are decreasing in intensity as the chloride ion concentration increases. While not clearly obvious in the first three 
figures of this group, figure 17, an expanded presentation of Am-11gand systems, shows the typical small shifts that occur in these $5 f^{n}-5 f^{n}$ transitions with complexation. It is this unique spectroscopic feature that can be exploited to examine complexation speciation.

A possible need exists to reexamine the stability constant values 6 that form the data bases used presently by the modelers. Such simple systems as the various oxidation state actinide ion-chloride Interactions have 11 terature values as follows for chloro complexation: $\mathrm{UO}_{2}^{++}+\mathrm{Cl}^{-}=\mathrm{UO}_{2} \mathrm{Cl}^{+}, \mathrm{K}_{2} \mathrm{Cl} l^{+}=58, \mathrm{~K} \mathrm{NpO}_{2} \mathrm{Cl}^{+}=.5, \mathrm{~K}_{\mathrm{PuO}_{2}} \mathrm{Cl}^{+}=.8 ;$ $\mathrm{U}^{4+}+\mathrm{Cl}^{-}-\mathrm{UCl}^{3+}, \mathrm{K}_{\mathrm{UCl} l^{3+}}=400, \mathrm{~K}_{\mathrm{NpCl} l^{3+}}=2, \mathrm{~K}_{\mathrm{PuCl} l^{3+}}=8 ; \mathrm{Pu}^{3+}+\mathrm{Cl}^{-}=$ PuCl $^{2+}, \mathrm{K}_{\text {PuCl }}{ }^{2+}=17, \mathrm{~K}_{\mathrm{AmCl}}{ }^{2+}=17$. Certalniy, something is Inconsistent for each grouping of redox-species-chloro complexes. Systematic comparisons for $\mathrm{MO}_{2}^{++}$lons $(M=U, \mathrm{~Np}, \mathrm{PU}$ ) would not support a 60 times larger constant for $\mathrm{vO}_{2}^{++}$when compared to $\mathrm{NpO}_{2}^{++}$and $\mathrm{PuO}_{2}^{++}$. A similar observation can be made for the $M^{4+}$ systems, and the finding that trivalent actinide lons form stronger chloro complexes than the tervalent lons is clearly wrong.

From the viewpoint of other potential repository sites, chloro stability constants are of little concern. The chloride ion concentrations are simply too low to matter: Yucca Mountain $-2 \times 10^{-4}$ $M-10^{-3} M_{.}{ }^{7}$ The situation in a salt repository site $1 \mathrm{~s}$ exactly opposite. A very large chloride concentration is expected if brines are present. This can lead to an increased inventory of radionuclides in a salt repository. Consider the system $\mathrm{Pu}^{3+}-\mathrm{Cl}^{-}$at a $\mathrm{pH} \leq 7$ and under reducing conditions; the stability constant $\mathrm{K}_{\mathrm{PuCl}}{ }^{2+}=17 ; \mathrm{Pu}^{3+}+\mathrm{Cl}^{-}=$ 
$\mathrm{PuCl}^{2+}$; the ratio of $\mathrm{PuCl} \mathrm{l}^{2+} / \mathrm{Pu}^{3+}$ is equal to $\left(\mathrm{K} \mathrm{PuCl}^{2+}\right) \cdot\left(\mathrm{A} \mathrm{Cl}^{-}\right)$[PBB3 brine] or $(17)(-27)=460=\mathrm{PuCl}^{2+} / \mathrm{Pu}^{3+}$. Since $\mathrm{Pu}^{3+}$ is the principal Ion in equilibrium with a solubility controlling solid phase, its concentration must be maintained in solution. Yet, $\mathrm{Pu}^{3+}$ is also in equilibrium with PuCl ${ }^{2+}$; and the concentration of $\mathrm{PuCl}^{2+}$ is approximately 2.5 orders of magnitude larger than the $\mathrm{Pu}^{3+}$ concentration. Thus the total solution inventory of Pu radionuclides that might be expected is greatly increased if the chloro complexation stability constant value of 17 is correct. While it is likely this value is too large, what is the correct stability constant? Even small complexation constants in the range of 1 can have a noticeable effect. If sensitivity calculations using the modeler's codes confirm the need for redetermination of any of the stability constants for the type of complexation systems discussed above, absorption spectroscopic techniques are the most promising experimental procedure. Data for the subtle actinide ion shifts due to complexation can be collected today in a superfor manner due to the advances of modern instrumentation. The data collected can also be analyzed in a much better way than 20 years ago due to the general avallability and improvement of computer peak deconvolution programs and also due to a superior understanding of formulating and applying solution activity coefficients.

Spectroscopic techniques are also needed for the resolution of the problem of tervalent actinide ion (especially $\mathrm{Pu}^{4+}$ ) complexation with carbonate ion. This problem has held the attention of many experimenters and has caused much effort to be expended in trying to confirm the earlier Russian value ${ }^{8}$ or to redetermine it accurately. It 
1s Iikely that a thorough understanding of the effects of carbonate complexation on a salt repository radionuclide containment site will be required for the site 11 cense.

At present, the most promising experimental approach is to examine the $\mathrm{Pu}^{4+}$-carbonate system at a $10 \mathrm{w} \mathrm{pH}$ and under $\mathrm{hlgh} \mathrm{CO}_{2}$ pressures so that no complications from hydrolysis are occurring, observation of the $470 \mathrm{~nm}$ Pu absorption line for perturbations due to $\mathrm{CO}_{3}^{-}$complexing would be made. Preliminary experiments have Indicated that the instrumental sensitivities needed exceed the capabilities of conventional UV-VIS-NIR spectrometers. This problem requires a more sensitive alternative technique to conventional absorption spectroscopy, such as optoacoustic (OA) (photoacoustic) spectroscopy. Stump et al. 9 have demonstrated the use of OA spectroscopy for speciation studies of aqueous actinide ions.

As in absorption spectroscopy, the problem in OA spectroscopy is to measure the energy absorbed ( $E_{\text {abs }}$ ) when a light beam or light pulse passes through an optically thin medium of length $l$ and absorption coefficient $\alpha$. The equation, $E_{\text {abs }}=E_{0} \alpha l$, is basically the same for elther technique; however the means of determining $E_{a b s}$ is radically different.

In conventional absorption work $\mathrm{E}_{\text {abs }}$ for a specles is determined as the difference between I (11ght intensity after passing through solvent) and I (11ght Intensity after passing through solvent plus solute). For weak absorption the problem arises of determining the difference between two large values. In $O A$ spectroscopy, however, $E_{a b s}$, is measured directly. The quantity evaluated is the amplitude (or integrated intens1ty) of a pressure wave that is generated as a result 
of the degradation of the electronic absorption energy into heat within a localized area defined by the light beam. Expansion by the heated area produces the pressure wave that is proportional to $\mathrm{E}_{\text {abs }}$ for systems that relax primarily by non-radiative processes. This $\mathrm{OA}$ method 18 of great advantage in weakly absorbing systems and offers the possiblity of Increasing the detection sensitivity by one to two orders of magnitude when compared to the l1mits of conventional absorption spectroscopy. 


\section{References}

1. Gehmecker, H. 1985. Chemische auftrennung der wertigkeltsstufen des plutonlums. Doctoral thesis, Johannes Gutenberg-University, Mainz, Federal Republic of Germany.

2. Nitsche, H. and Edelsteln, N.M. 1985. Determination of the solubilities and complexation of waste radionuclides pertinent to geological disposal at the Nevada tuff site. Topical report. Solubilities and speciation of actinide lons in near-neutral solution, LBL-18900, Lawrence Berkeley Laboratory, Berkeley, CA., Jan. 1985, and references therein.

3. Marcus, Y., GIvon, M., and Shiloh, M. 1965. The chemistry of the trivalent actinides in aqueous solutions and their recovery. Proc. 3rd Intern. Conf. Peaceful Uses At. Energy, Geneva, 1965, United Nations $10,588-596$.

4. Shiloh, M. and Marcus, Y. 1966. A spectrophotometric study of trivalent actinide complexes in solution. II-Neptunium and Plutonium. J. Inorg. Nucl, Chem, 28, 2725-27722

5. Marcus, Y. and Shiloh, M. 1969. A spectrophotometric study of trivalent actinide complexes in solution. IV. Americlum with chloride I1 gands. Israel J. Chem. I, 31-43.

6. Phillips, S., Phlllips, C., and Skeen, J. 1985. Hydrolys1s, formation and Ionization constants at $25^{\circ} \mathrm{C}$, and at high temperature-h1gh 1onlc strength. LBL-14996, Lawrence Berkeley Laboratory, Feb. 1985, and reference therein.

7. Ogard, A. and Kerr18k, J. 1984. Groundwater chemistry along flow paths between a proposed repository site and the accessible 
environment. UR-LA-10188, Los Alamos National Laboratory, Los Alamos, New Mexico, 47 pp.

8. Cleveland, J.M. 1970. The Chemistry of Plutonium, Gordon and Breach, New York, p. 120.

9. Stumpe, R., KIm, J., Schrepp, H., and Walther, H. 1984, Speciation of actinide lons in aqueous solution by laser-induced pulsed photoacoust1c spectroscopy. Appl. Phys. B 34, 203-206. 


\begin{tabular}{|c|c|c|c|c|c|c|}
\hline \multirow[t]{2}{*}{ Solution } & \multirow{2}{*}{$\begin{array}{c}\text { Oxidation } \\
\text { State }\end{array}$} & \multirow{2}{*}{$\begin{array}{l}\text { Initial } \\
\text { conditions }\end{array}$} & \multicolumn{4}{|c|}{ Determination or oxidation States } \\
\hline & & & S1L1ca Gel & LIChrosort & Dowex 50 & LaF 3 -precp. \\
\hline 1 & $\begin{array}{l}\mathrm{Pu}^{24} \\
\mathrm{Pu}^{4+} \\
\mathrm{PuO}_{2 \mathrm{i}}^{+} \\
\mathrm{PuO}_{2}^{2+}\end{array}$ & $\begin{array}{c}50,0 \\
50,0 \\
- \\
- \\
\end{array}$ & $\begin{array}{c}52 \pm 1.5 \\
48 \pm 1.5 \\
- \\
-\end{array}$ & $\begin{array}{l}- \\
- \\
- \\
-\end{array}$ & $\begin{array}{l}- \\
- \\
- \\
-\end{array}$ & $\begin{array}{l}- \\
- \\
- \\
-\end{array}$ \\
\hline 2 & $\begin{array}{l}\mathrm{Pu}^{2+} \\
\mathrm{Pu}^{4+} \\
\mathrm{PuO}_{2}^{+} \\
\mathrm{PuO}_{2+}\end{array}$ & $\begin{array}{l}- \\
50,0 \\
50.0 \\
-\end{array}$ & $\begin{array}{c}- \\
53 \pm 1,5 \\
47 \pm 1,5 \\
-.\end{array}$ & $\begin{array}{c}- \\
54 \pm 1.5 \\
46 \pm 1.5 \\
-\end{array}$ & $\begin{array}{c}- \\
55 \pm 1.5 \\
45 \pm 1.5 \\
-\end{array}$ & $\begin{array}{c}- \\
53 \pm 1,5 \\
47 \pm 1,5 \\
-\end{array}$ \\
\hline 3 & $\begin{array}{c}\mathrm{Pu}^{2+} \\
\mathrm{Pu}^{4+} \\
\mathrm{PuO}_{2}^{+} \\
. \mathrm{PuO}_{2}^{2+}\end{array}$ & $\begin{array}{l}- \\
50.0 \\
- \\
50.0\end{array}$ & $\begin{array}{c}- \\
50 \pm 1,5 \\
- \\
50 \pm 1,5\end{array}$ & $\begin{array}{c}- \\
52 \pm 1.5 \\
- \\
48 \pm 1.5\end{array}$ & $\begin{array}{c}- \\
54 \pm 1.5 \\
- \\
46 \pm 1.5\end{array}$ & $\begin{array}{c}- \\
50 \pm 1,5 \\
- \\
50 \pm 1,5\end{array}$ \\
\hline 4 & $\begin{array}{l}\mathrm{Pu}^{3+} \\
\mathrm{Pu}^{4+} \\
\mathrm{PuO}_{2}^{+} \\
\mathrm{PuO}_{2+}\end{array}$ & $\begin{array}{c}33,3 \\
33,3 \\
33,3 \\
-\end{array}$ & & $\begin{array}{r}36 \pm 1.0 \\
34 \pm 1.0 \\
28 \pm 1.0 \\
1 \pm 0.3\end{array}$ & & $71 \pm 2,0$ \\
\hline
\end{tabular}

Table 1. Analysis of oxidation state Determination for the Plutonium System in Synthet1c Groundwater. 
Table 2. Absorption Parameters for U, Np, Pu, Am, and Tc

$\begin{array}{cccc} & \text { Wave Length } & \text { Molar Absorptivity } & \text { Sensitivity } \\ (\text { mole/l) } & (\ell / m o l e-c m) & (\mathrm{mm}) & \left(A=5 \times 10^{-4}\right)\end{array}$

\begin{tabular}{|c|c|c|c|}
\hline $\mathrm{Am}^{3+}$ & 503 & 380 & $1.3 \times 10$ \\
\hline $\operatorname{sm}^{4+}$ & 456 & 30 & $1.5 \times 10^{-5}$ \\
\hline
\end{tabular}

$\mathrm{Pu}^{3+}$

$\mathrm{Pu}^{4+}$

$\mathrm{PuO}_{2}^{+}$

$\mathrm{PuO}_{2}^{2+}$

$\mathrm{Np}^{3+}$

$\mathrm{Np}^{4+}$

$\mathrm{NpO}_{2}^{+}$

$\mathrm{NpO}_{2}^{2+}$

$\mathbf{u}^{3+}$

$u^{4+}$

$\mathrm{UO}_{2}^{+}$

$\mathrm{UO}_{2}^{2+}$

$\mathrm{Tc}^{3+}$

$\mathrm{TC}^{4+}$

$\mathrm{TCO}_{4}^{-}$
600

470

568

830

786

723

980

1223

520

650

415

340

485

246

\section{8}

55

19

550

44

127

395

45

140

58

$-$

8
$1.3 \times 10^{-5}$

$9.0 \times 10^{-6}$

$2.6 \times 10^{-5}$

$9.0 \times 10^{-7}$
$1.1 \times 10^{-5}$

$4.0 \times 10^{-6}$

$1.3 \times 10^{-6}$

$1.1 \times 10^{-6}$

$3.5 \times 10^{-6}$

$8.6 \times 10^{-6}$

$6.3 \times 10^{-5}$

4,500

$1.1 \times 10^{-7}$

4,300

$1.2 \times 10^{-7}$

6,220

$8.0 \times 10^{-8}$ 


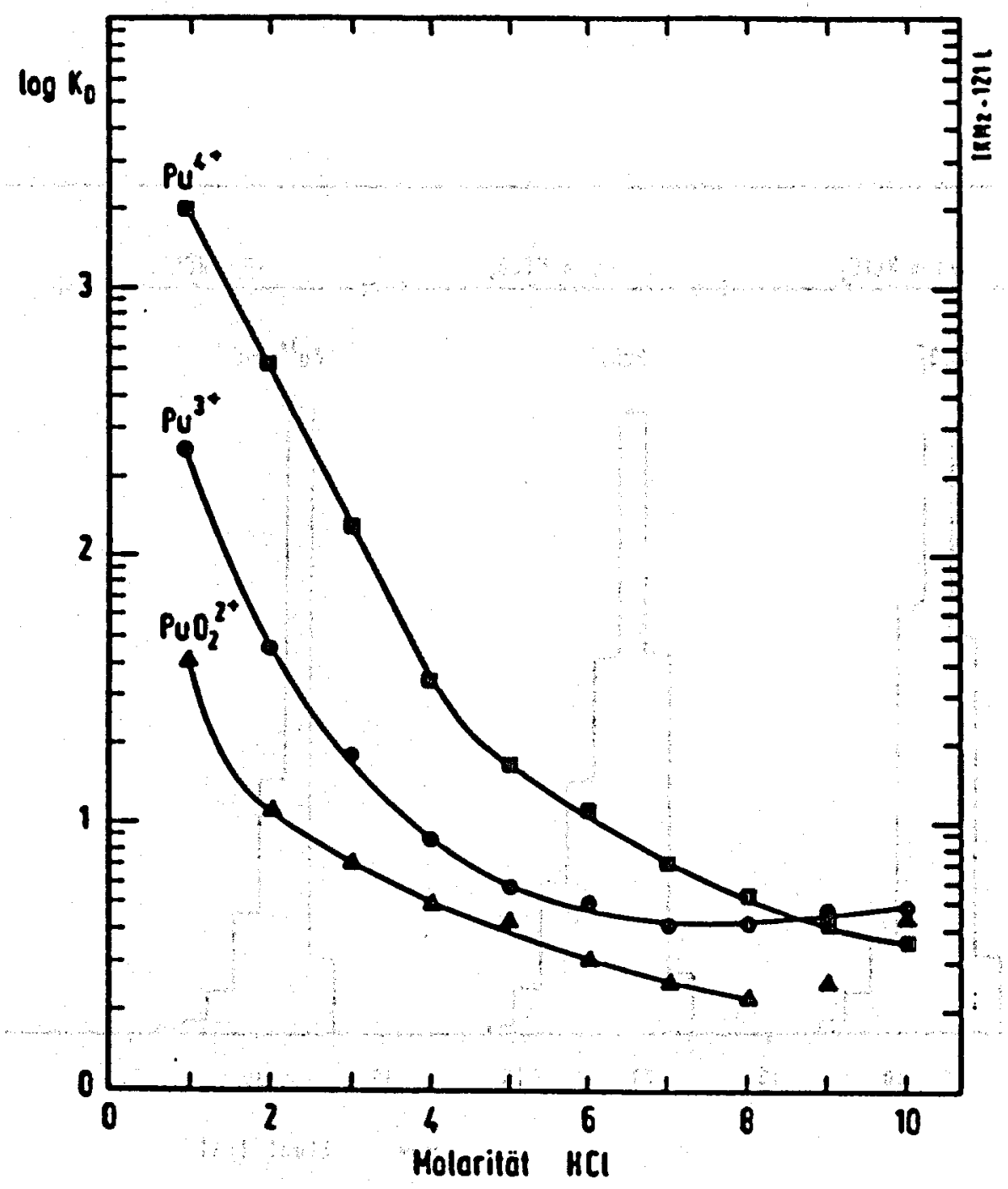

Figure 1. Distribution Coefficients for $\mathrm{Pu}^{3+}, \mathrm{Pu}^{4+}$ and $\mathrm{PuO}_{2}^{2+}$ in the System Dowex AG50-X8, Hydrochloric Ac1d. 


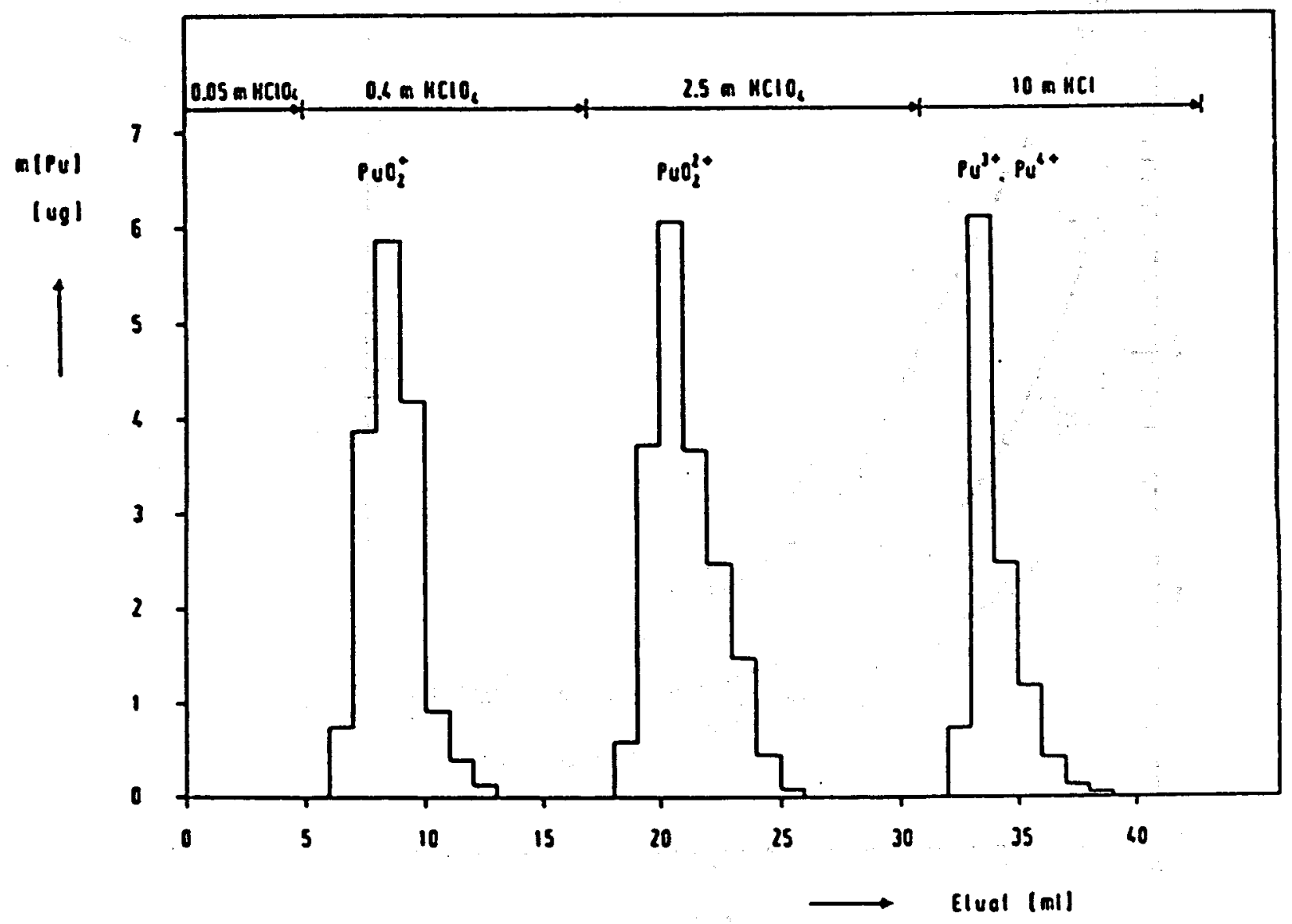

Figure 2. Eluation-Peaks for $\mathrm{Pu}^{3+}, \mathrm{Pu}^{4+}, \mathrm{PuO}_{2}^{+}$, and $\mathrm{PuO}_{2}^{2+}$ for a $(100 \times 4) \mathrm{mm}$ DoweX AG50-X8 Column, Various Acidities. 


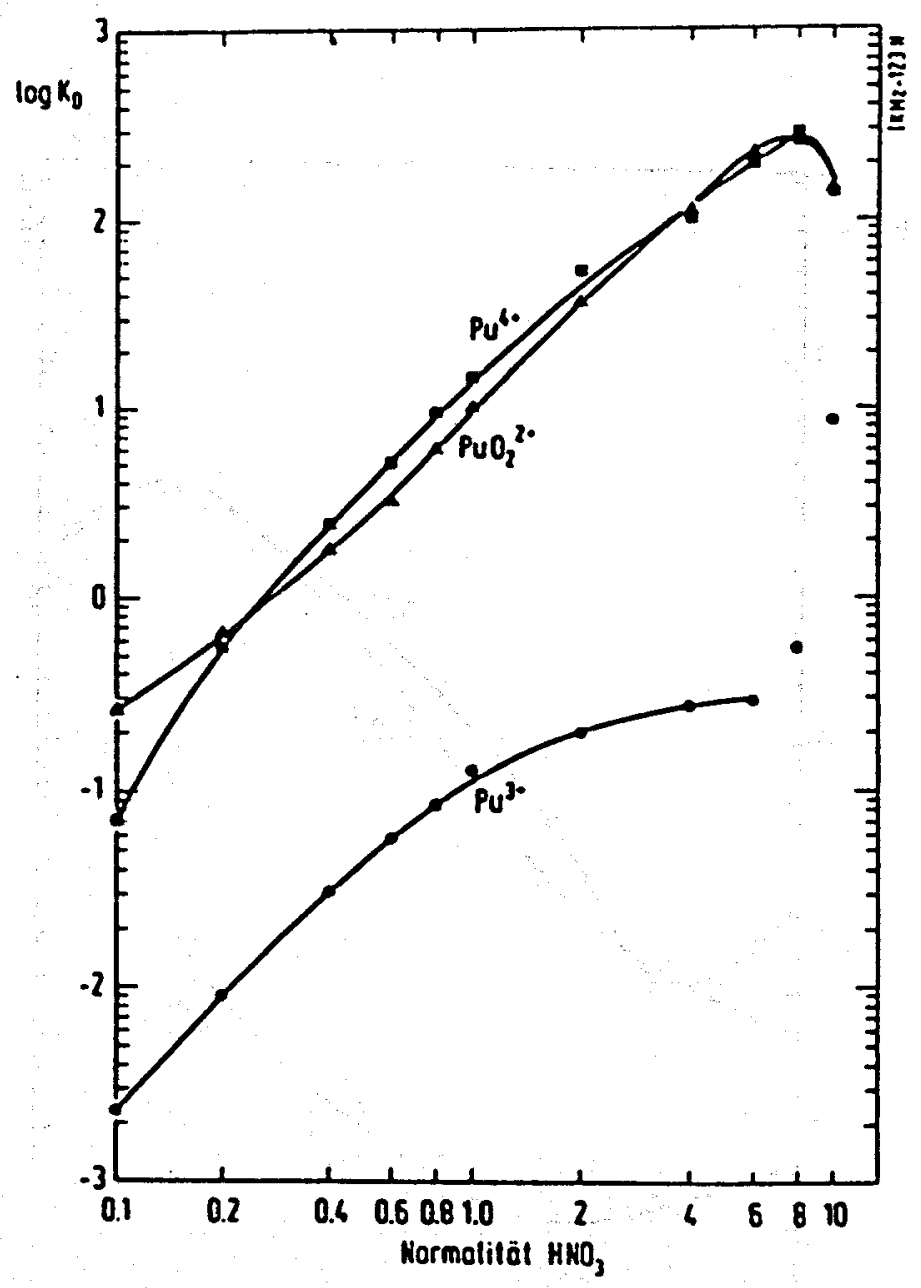

Figure 3. Distribution Coefficients for $\mathrm{Pu}^{3+}, \mathrm{Pu}^{4+}$, and $\mathrm{PuO}_{2}^{+}$in the System $\mathrm{TBP} / \mathrm{HNO}_{3}$. (Liquid-Liquid Phase Extraction). 


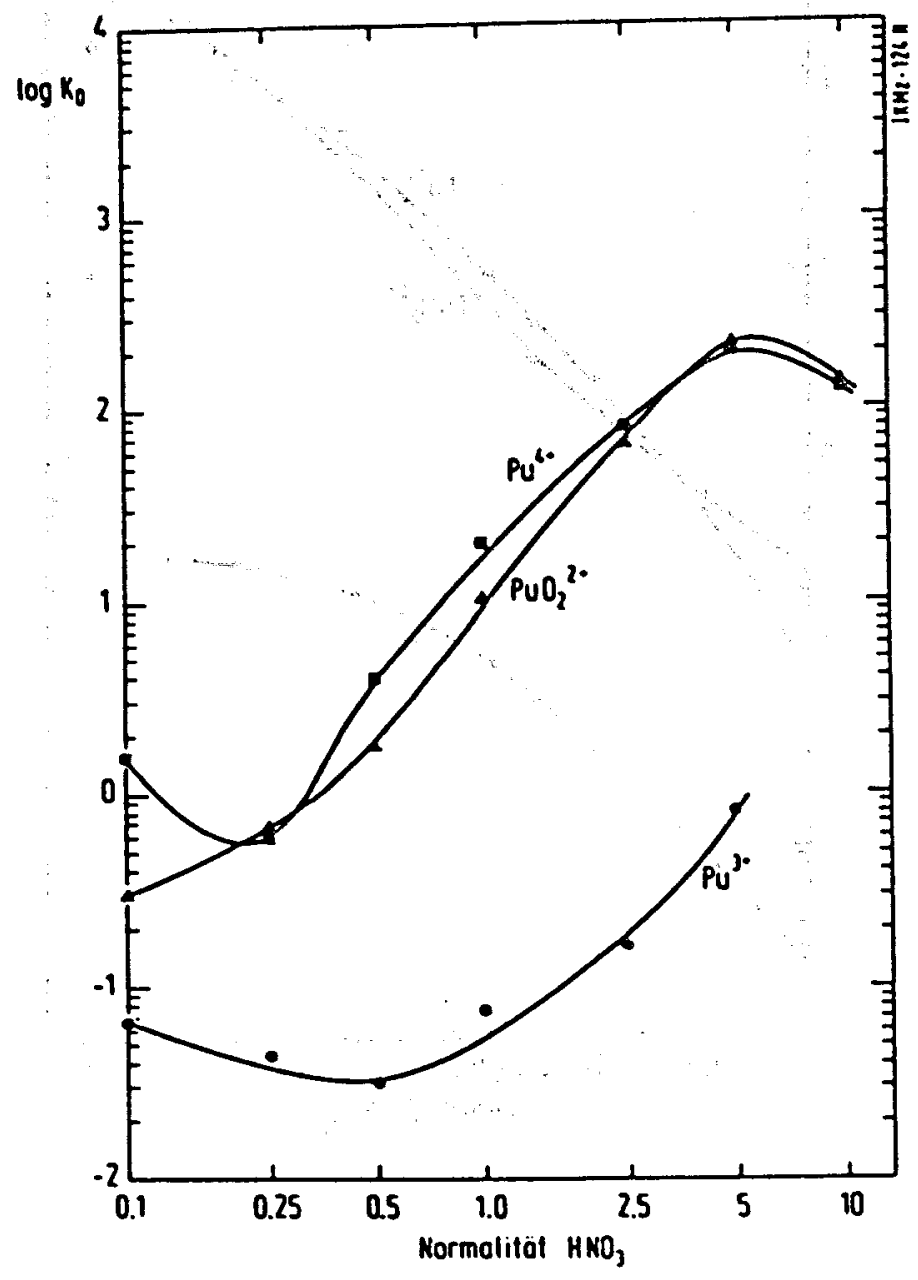

Figure 4. Distribution Coefficients for $\mathrm{Pu}^{3+}, \mathrm{Pu}^{4+}$, and $\mathrm{PuO}_{2}^{2+}$ in the System $\mathrm{TBP} / \mathrm{HNO}_{3} \cdot$ (TBP Sorbed on an Inert stationary Phase). 

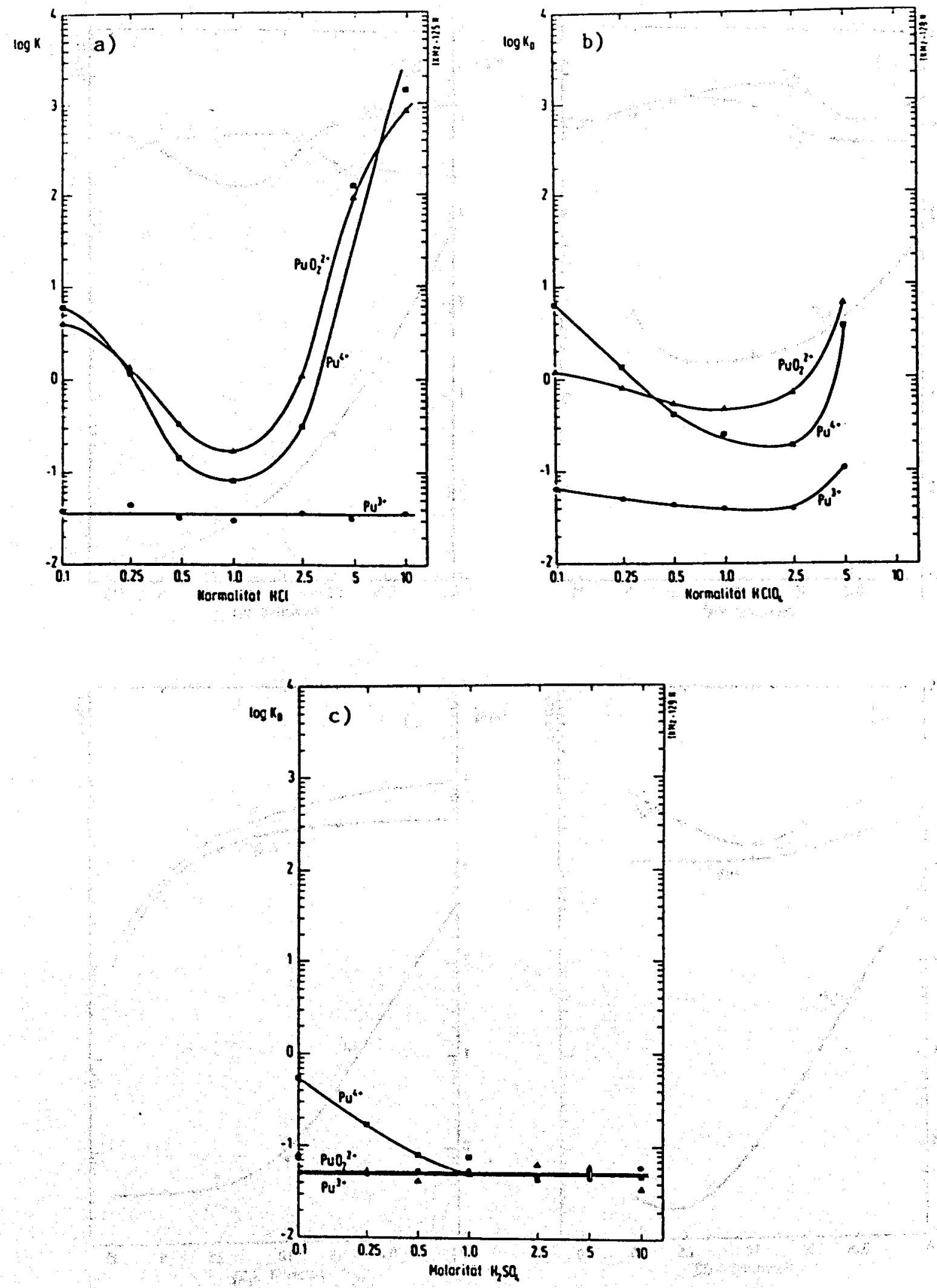

Figure 5. Distribution Coefficlents for $\mathrm{Pu}^{3+}, \mathrm{Pu}^{4+}$ and $\mathrm{PuO}_{2}^{2+}$ in the System TBP/ACid. a) $\mathrm{HCl}$, b) $\mathrm{HClO}_{4}$, c) $\mathrm{H}_{2} \mathrm{SO}_{4}$ 

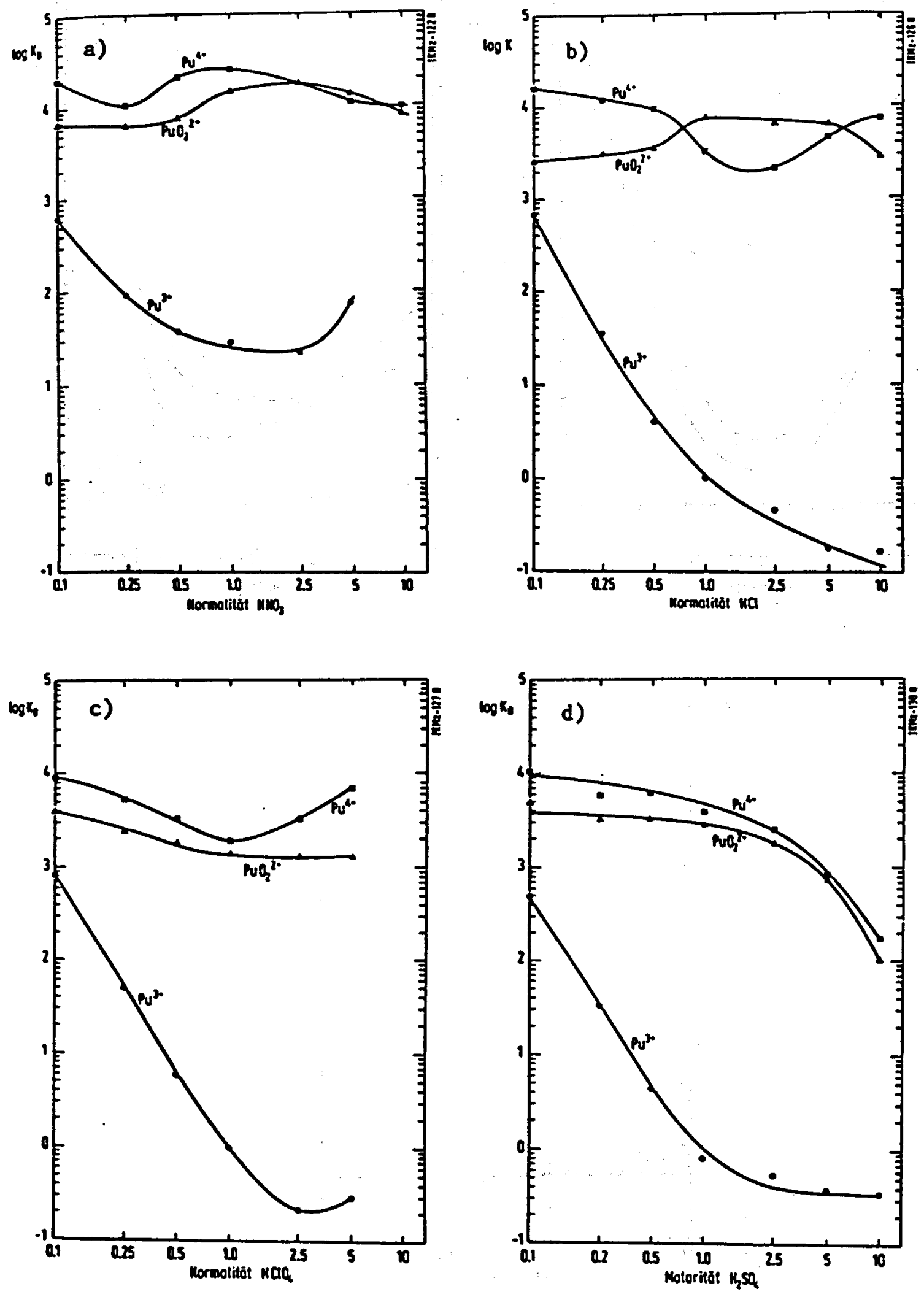

Figure 6. Distribution Coefficients for $\mathrm{Pu}^{3+}, \mathrm{Pu}^{4+}$, and $\mathrm{PuO}_{2}^{2+}$ in the System HDEHP/Mineral ACids. a) $\mathrm{HNO}_{3}$, b) $\mathrm{HCl}$, c) $\mathrm{HClO}_{4}$, and d) $\mathrm{H}_{2} \mathrm{SO}_{4}$ 


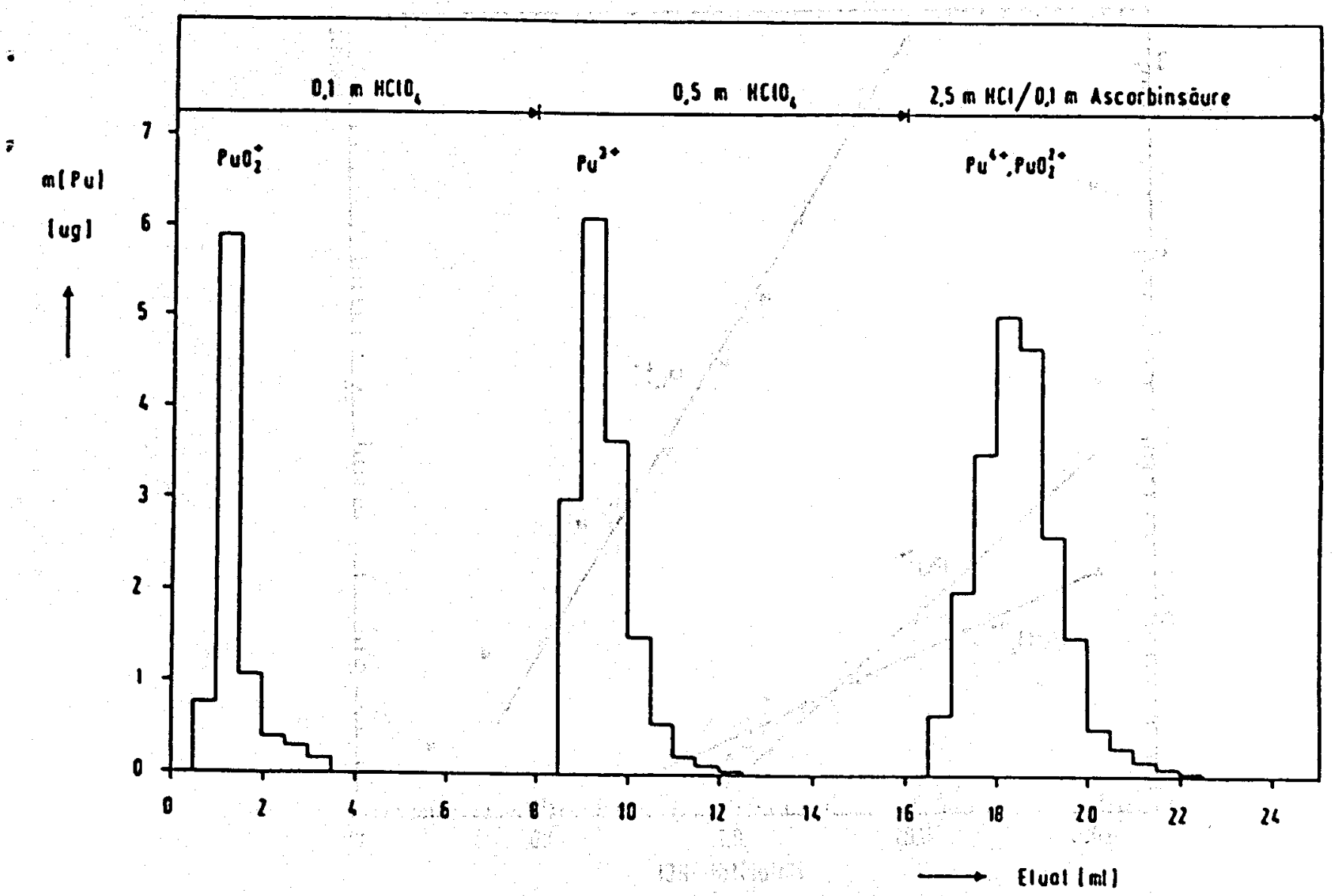

Figure 7. Elution Position of $\mathrm{Pu}^{3+}, \mathrm{Pu}^{4+}, \mathrm{PuO}_{2}^{+}$, and $\mathrm{PuO}_{2}^{2+}$ for a HDEHP/Inert Support/Acid system.

Eluent: $0.1 \mathrm{M} \mathrm{HClO}_{4}\left(\mathrm{PuO}_{2}^{+}\right), 0.5 \mathrm{M} \mathrm{HClO}_{4}\left(\mathrm{Pu}^{3+}\right), 2.5 \mathrm{M} \mathrm{HCl}$

$+0.1 \mathrm{M}$ Asorbic Acld $\left(\mathrm{Pu}^{4+}, \mathrm{PuO}_{2}^{2+}\right)$

Temperature: $22^{\circ} \mathrm{C}$

Flow Rate: $0.20 \mathrm{ml} / \mathrm{min}$

Column size: $(100 \times 4) \mathrm{mm}$ 


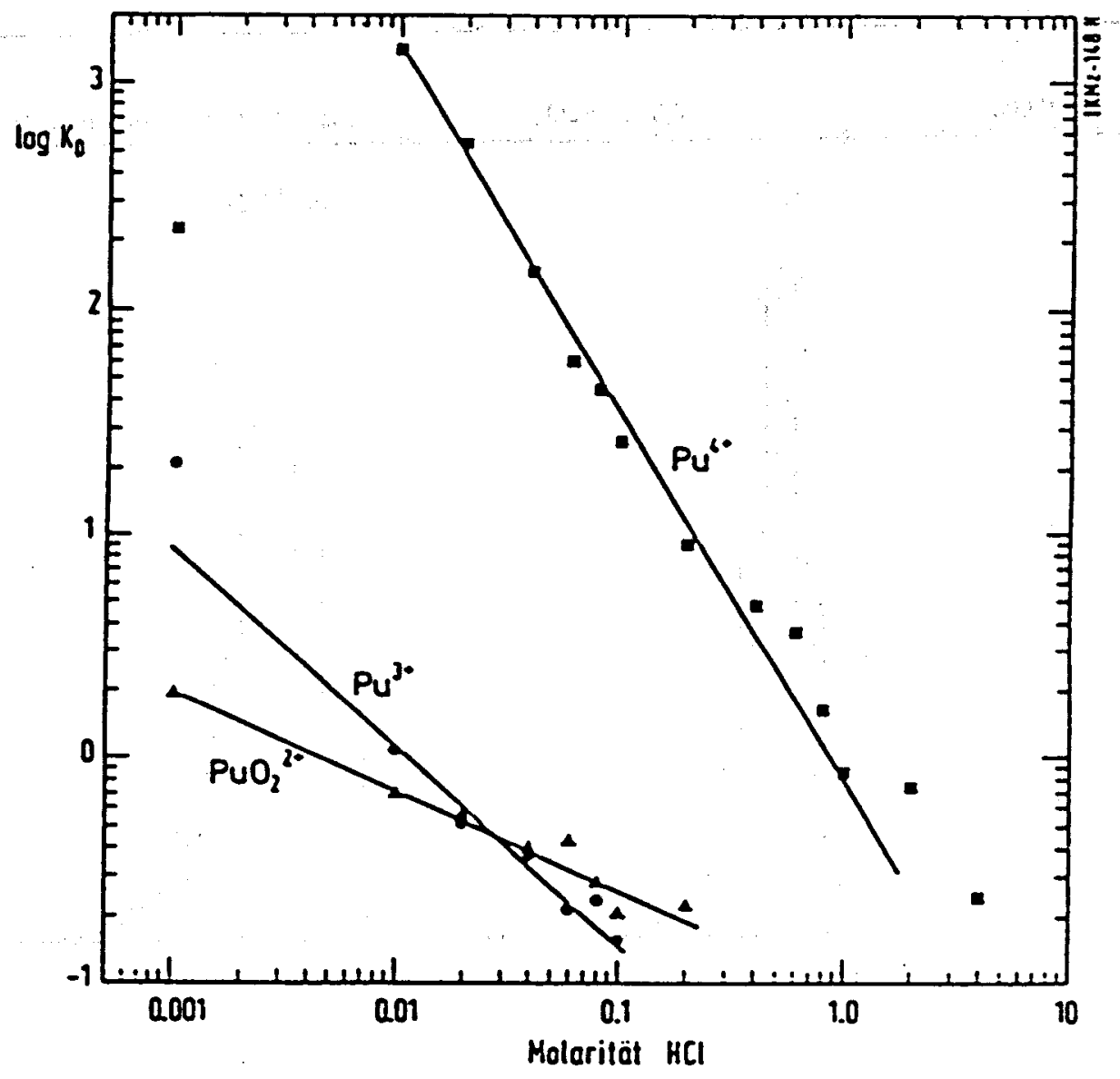

Figure 8. Distribution Coefficients for the Absorption of $\mathrm{Pu}^{3+}, \mathrm{Pu}^{4+}$, and $\mathrm{PuO}_{2}^{2+}$ on LiChroprep SI 60 as a Function of Hydrochloric Acid Concentration. 


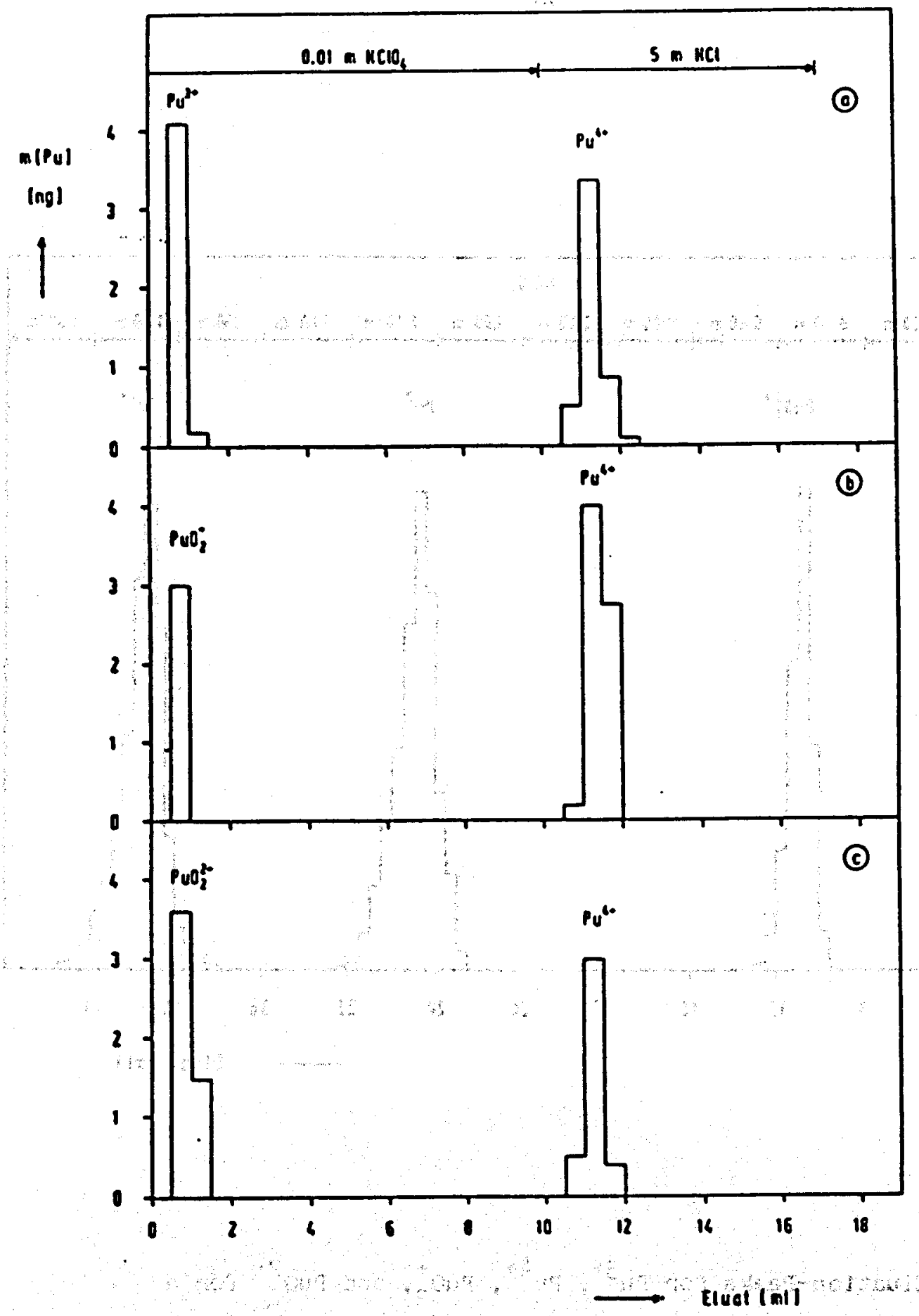

Figure 9. Separation of Various Plutonium Oxidation State Mixtures on a LiChropher SI 100 Column/Acid System

a) $\mathrm{Pu}^{3+} / \mathrm{Pu}^{4+} ;$ b) $\mathrm{Pu}^{4+} / \mathrm{PuO}_{2}^{+} ;$c) $\mathrm{Pu}^{4+} / \mathrm{PuO}_{2}^{2+}$ Column size: $(100 \times 4) \mathrm{mm}$

Flow Rate: $0.3 \mathrm{ml-min}^{-1}-\mathrm{cm}^{-2}$ (Sorption)

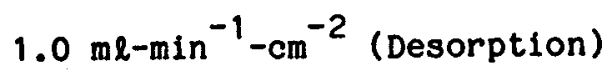




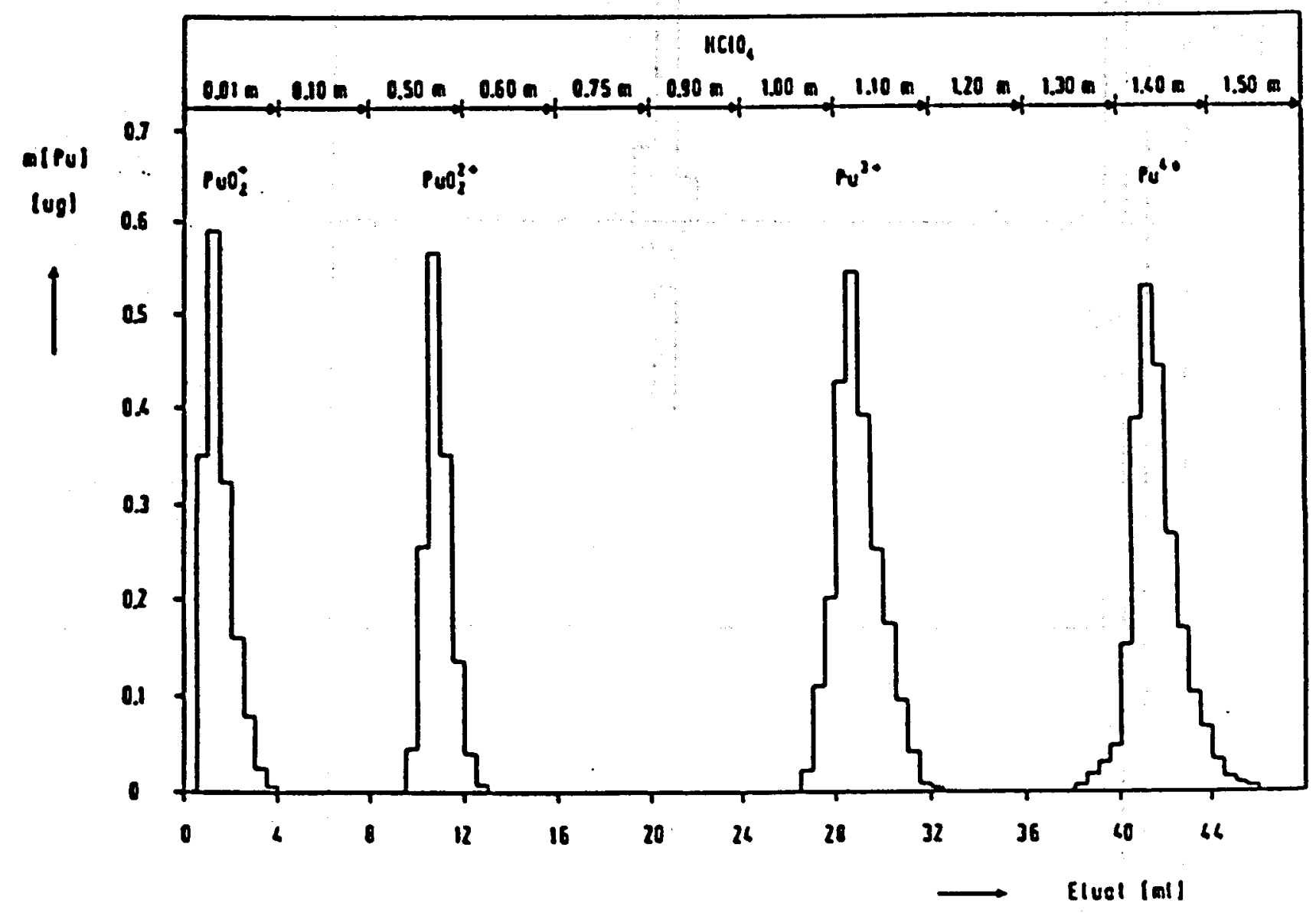

Figure 10. Eluation-Peaks for $\mathrm{Pu}^{3+}, \mathrm{Pu}^{4+}, \mathrm{PuO}_{2}^{+}$, and $\mathrm{PuO}_{2}^{2+}$ for a (100x4)mm-cation exchange LiChrosorb/HClO 4 system. 


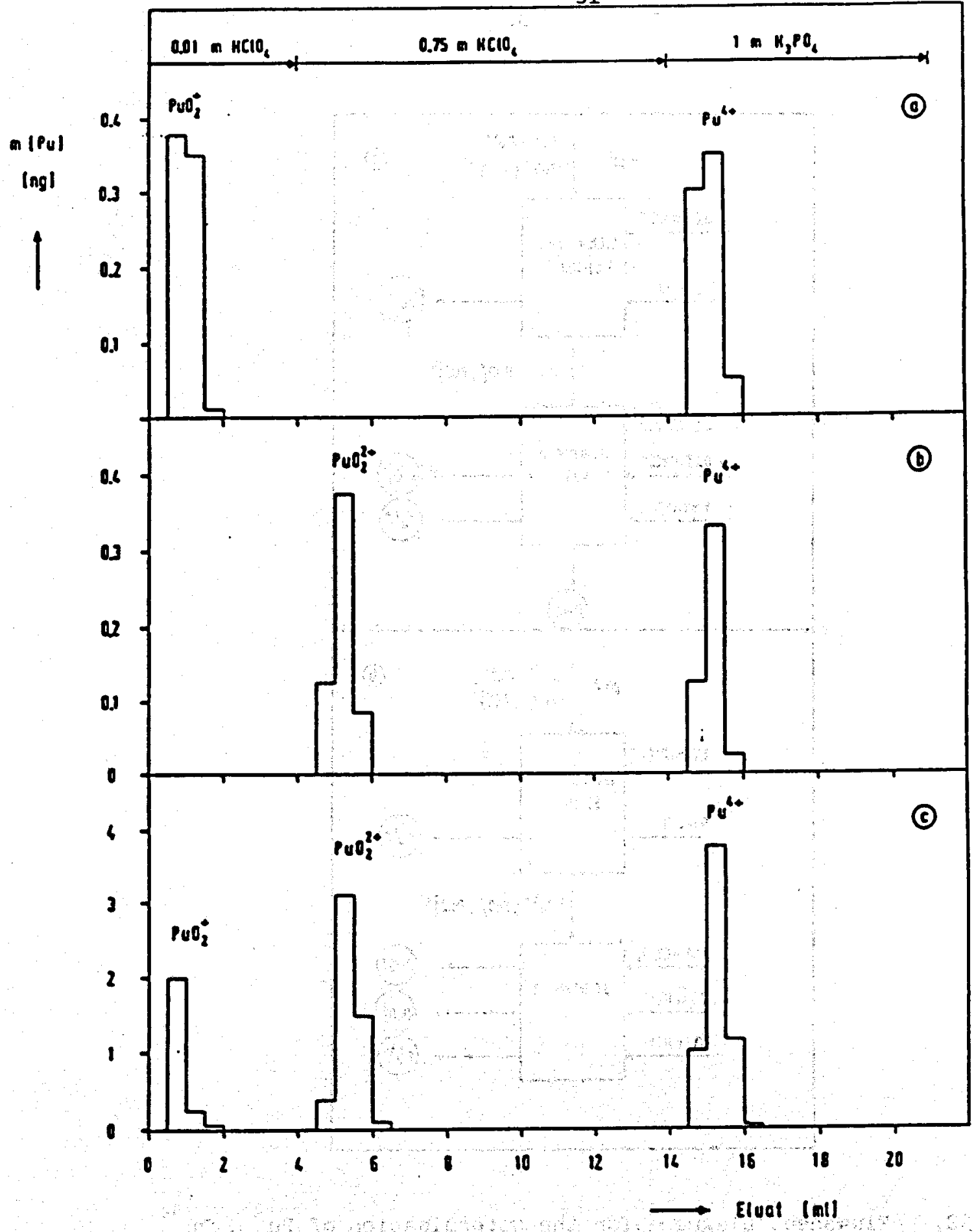

Figure 11. Separation of Various Plutonium Oxidation State Mixtures on a Sulfonated Cation-Ion Exchange LIchropher SI 100 Column/Ac1d Systems.

a) $\mathrm{Pu}^{4+} / \mathrm{PuO}_{2}^{+}$; b) $\mathrm{Pu}^{4+} / \mathrm{PuO}_{2}^{2+}$; c) $\mathrm{Pu}^{4+} / \mathrm{PuO}_{2}^{+} / \mathrm{PuO}_{2}^{2+}$ Column Size: $(100 \times 4) \mathrm{mm}$

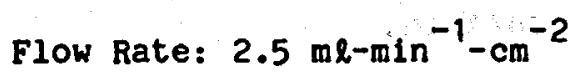

$a, b)-1.5 \mathrm{ng} P \mathrm{P}_{\text {; }}$ c) $-15 \mathrm{ng} \mathrm{Pu}$ 


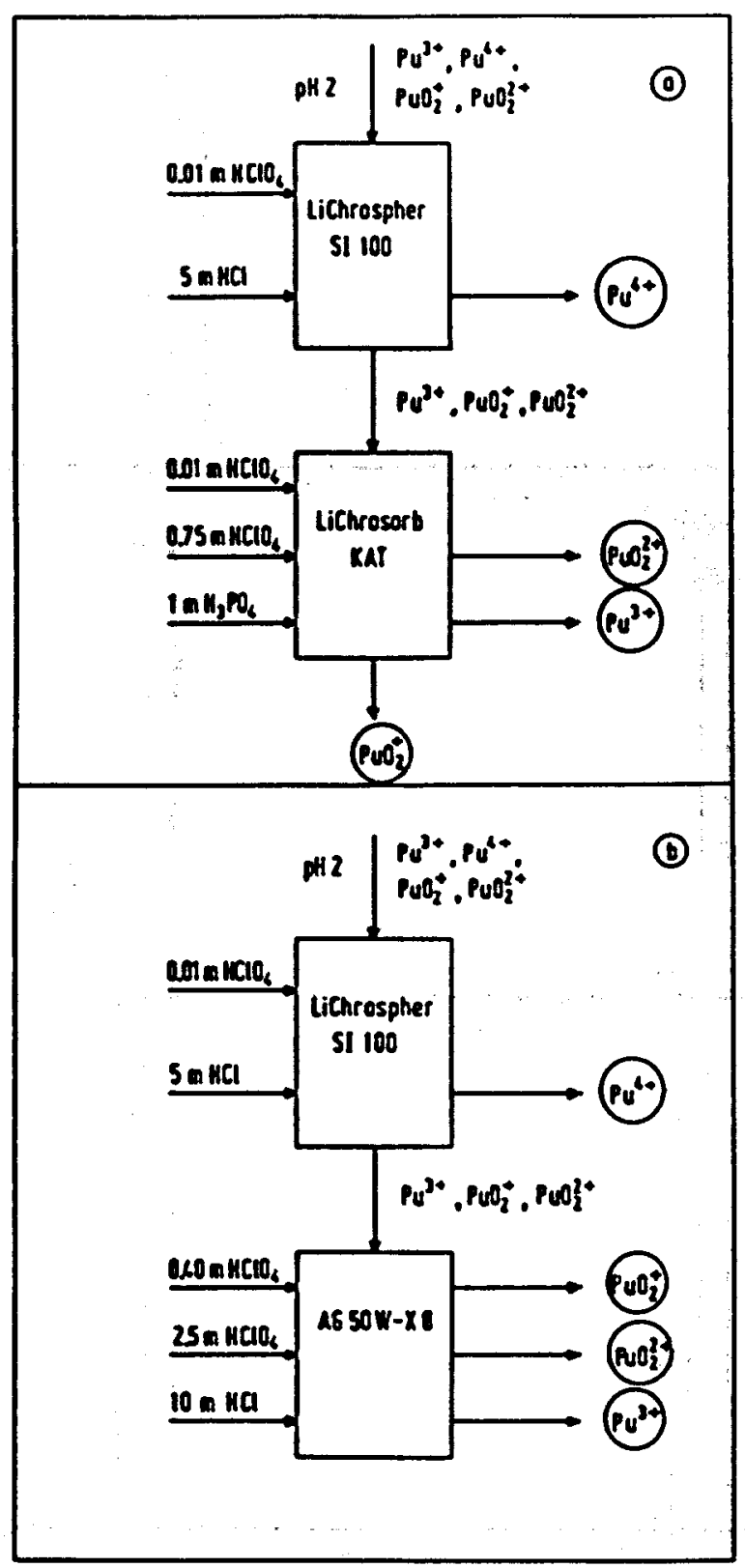

Figure 12. Flowsheet Diagrams for the Determination of $\mathrm{Pu}^{3+}, \mathrm{Pu}^{4+}$, $\mathrm{PuO}_{2}^{+}$, and $\mathrm{PuO}_{2}^{2+}$ Oxidation State with Ion-Exchange Chromatography. a) Silica Gel (LIChrospher SI 100)/Acid + Sulfonated Sillca Cation Ion-Exchange Material/Acid;

b) Silica Gel (LiChrospher SI 100)/Acid + Dowex 50W-XB Cation Ion-Exchange Resin/Acid. 


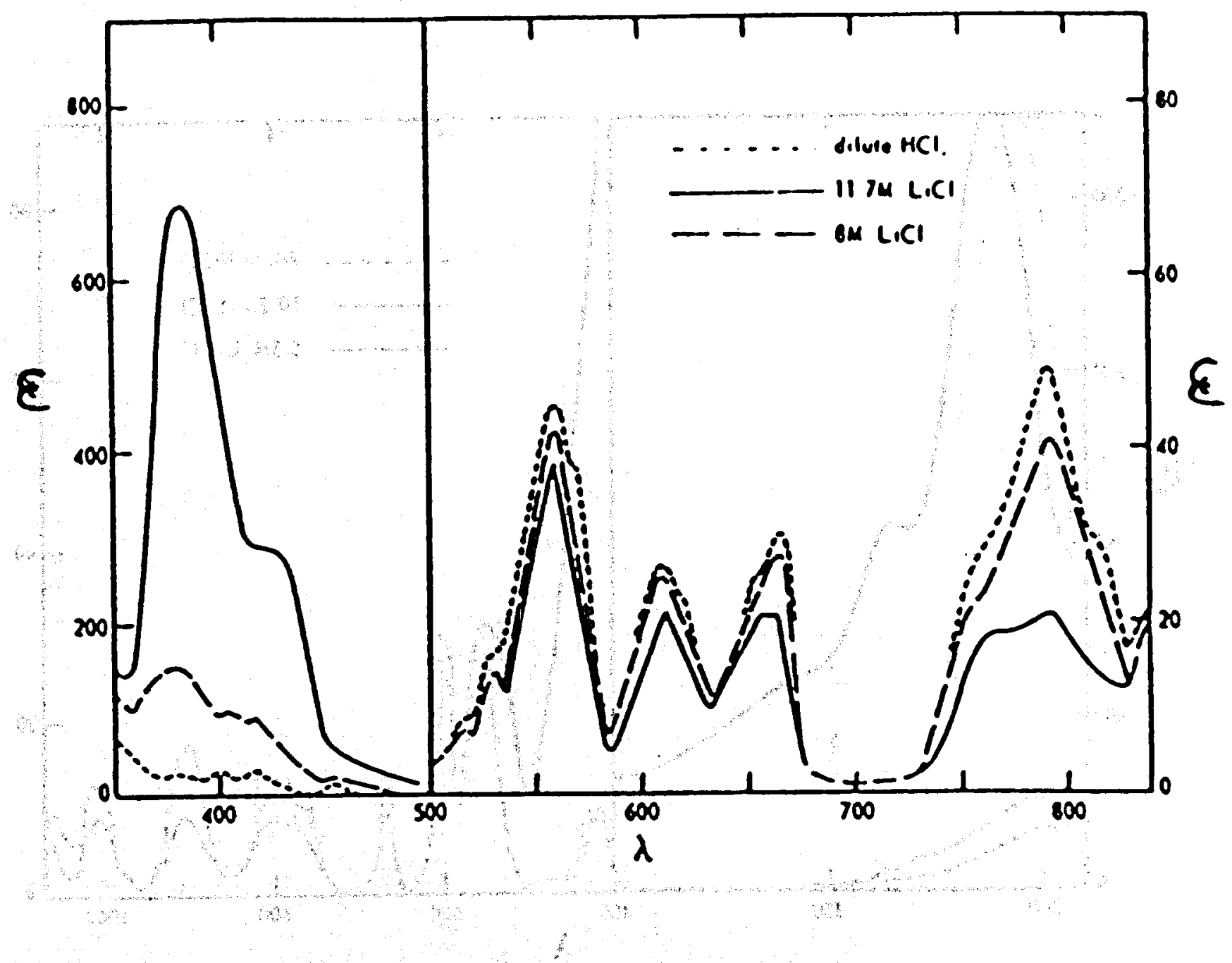

Figure 13. Absorption Spectrum of Neptunium(III) at Various Chloride Concentrations. 


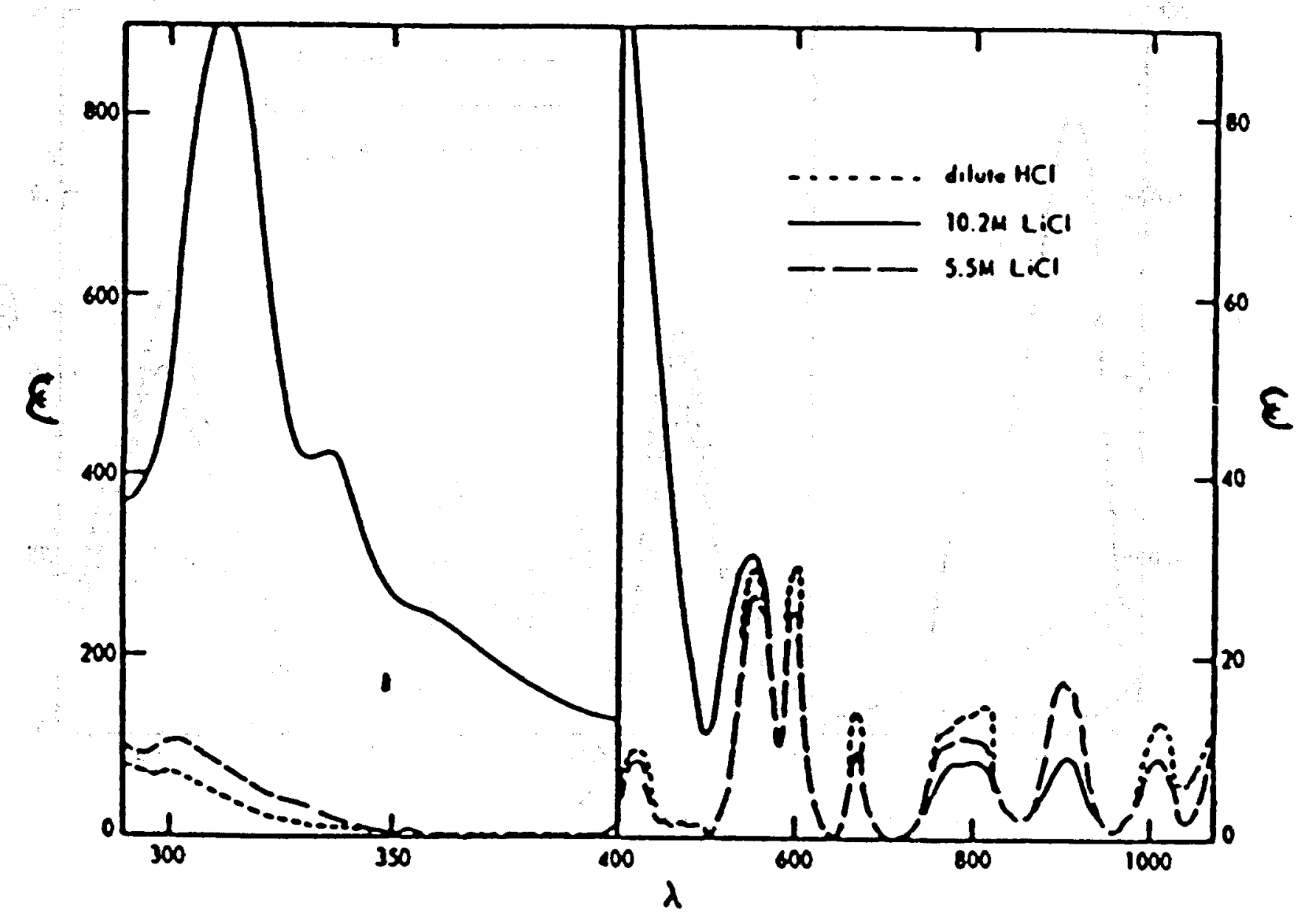

Figure 14. Absorption Spectrum of Plutonium(III) at Various Chloride Concentrations. 


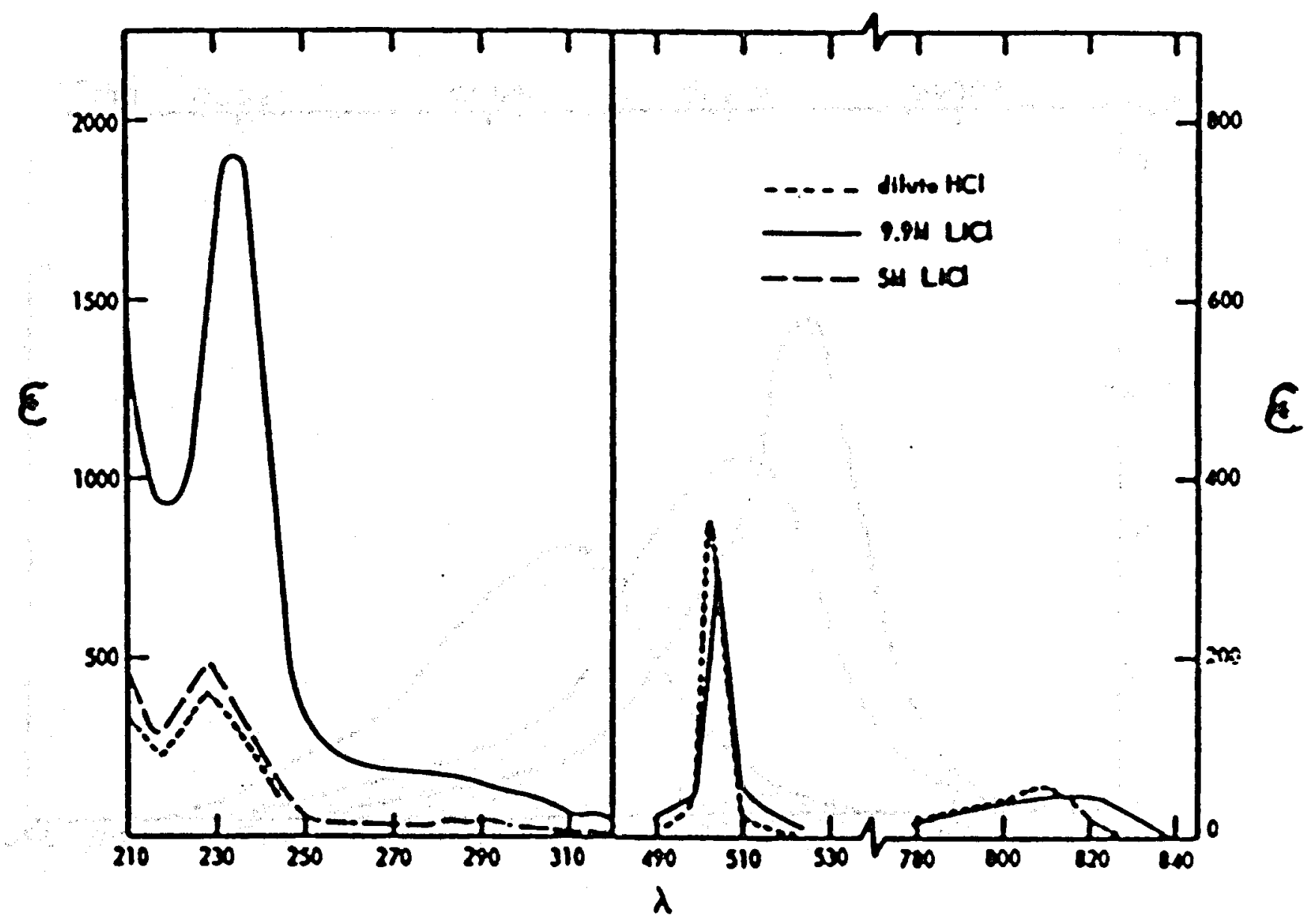

Figure 15. Absorption Spectrum of Americium(III) at Various Chloride Concentrations. 


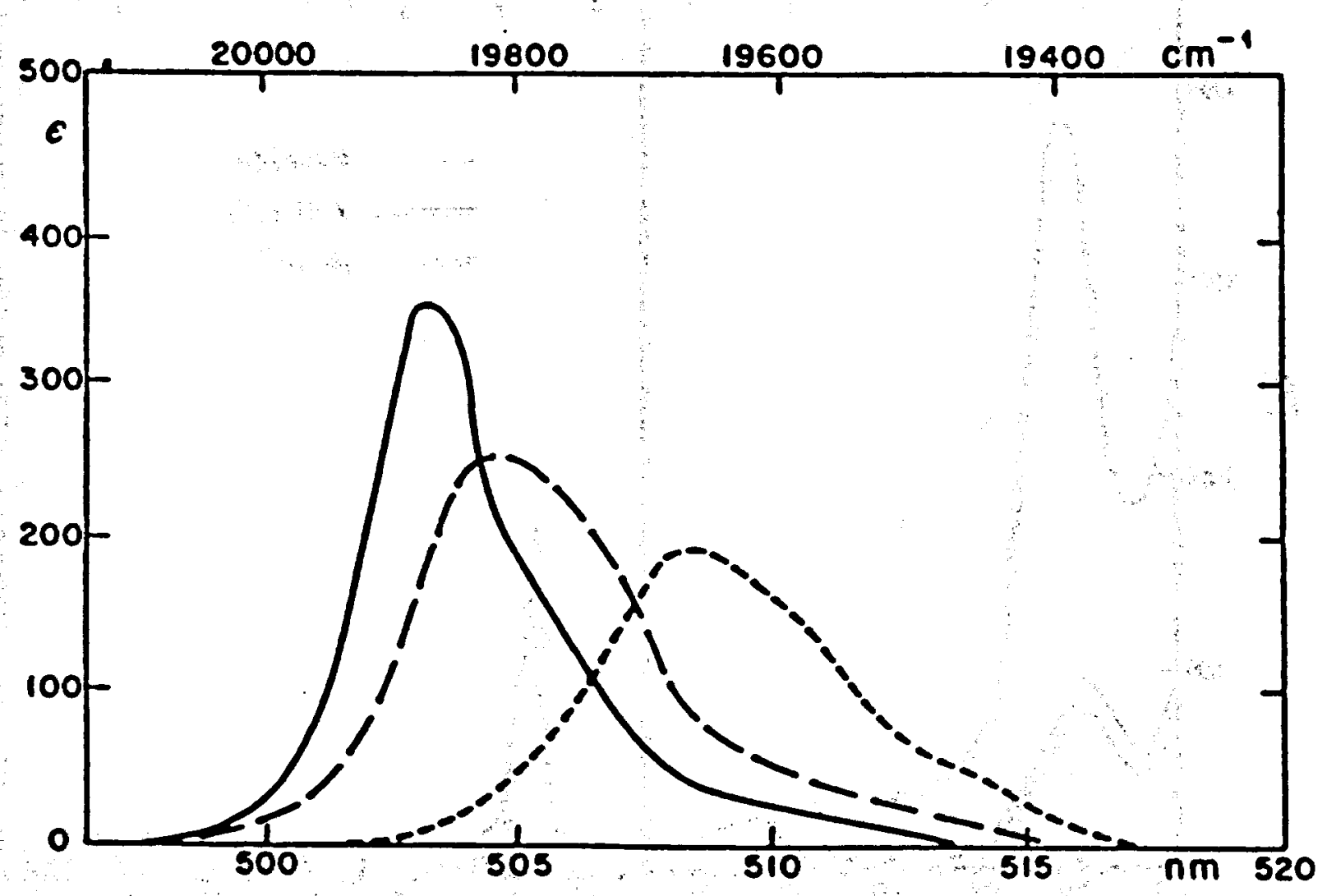

Figure 16. The $503 \mathrm{~nm}$ Band in the Americium(III) Spectrum:

$$
\begin{aligned}
& -1 \mathrm{M} \mathrm{HClO}_{4},--11.4 \mathrm{M} \mathrm{Li} \mathrm{Br}, \\
& ---6.0 \mathrm{M} \mathrm{K}_{2} \mathrm{CO}_{3} \text { solutions. The Molar Absorbance } \varepsilon \text { in } \\
& \mathrm{M}^{-1} \mathrm{~cm}^{-1} \text { of } 0.6-2.0 \mathrm{mM} \text { Americium Solutions is Plotted } \\
& \text { Against the Wavelength. }
\end{aligned}
$$

